Afiliada à

Associação Brasileira A B E C

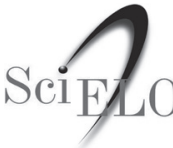

D Clarivate Analytics

scopus

Geoscience

EBSCO

PUBLISHING

Provider of EBSCOhost ${ }^{\circ}$

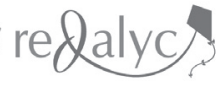

\section{The importance of education}

If you think education is expensive, try ignorance

Derek Curtis Bok

President of Harvard University (1971-1991)

Professor Hubert Roeser (Escola de Minas / UFOP) tells us that in the period of exception in Brazil, in a conversation with Dr. José Pedro Xavier da Veiga (former student of Escola de Minas), he heard that the problem would not be the communists (read the Russians), but the yellow ones (he referred to the Japanese, Koreans, etc.). And he was right: Japan, the Asian tigers and, more recently, the Chinese giant.

The key to success was investment in education. According to Lochner, Lance \& Moretti, Enrico, 2004, (The Effect of Education on Crime: Evidence from Prison Inmates, Arrests, and Self-Reports. American Economic Review. 94. 155-189), they estimated that the social savings from crime reduction associated with high school graduation (for men) is about $14-26$ percent of the private return.

According to the same authors, the gains from this reduction are significant: an increase of $1 \%$ in the education rate of the male population would generate a gain of US $\$ 1.4$ billion annually.

Also, the results of investments in research can be seen with a "naked eye", and we have examples such as Embrapa (ex: agribusiness), Petrobras (continental platform), etc. Worldwide, the vaccine to combat the pandemic, which today threatens the entire population, is another demonstration of applications in science. We can list more results, but the most important thing is that Brazilian universities, even with low investments in research, have given positive responses.

Of course, ignorance is expensive, even so, we see an increase in "antagonists", who believe that the land is flat, that they are against vaccinating, and so on. If this continues, one can imagine that they will soon ask the church to condemn Galileo again.

\section{Prof. Jório Coelho ${ }^{1}$ \\ https://orcid.org/0000-0001-5041-5085}

${ }^{1}$ Editor Chefe

Universidade Federal de Ouro Preto -UFOP, Escola de Minas, Departamento de Geologia

Ouro Preto - Minas Gerais - Brasil

E-mail: editor@rem.com.br 